Discussion Paper No. 05-96

\title{
Training, Mobility, and Wages: Specific Versus General Human Capital
}

Alfred Garloff and Anja Kuckulenz

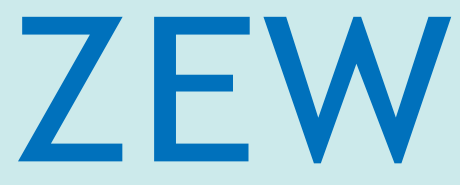

Zentrum für Europäische Wirtschaftsforschung $\mathrm{GmbH}$

Centre for European

Economic Research 
Discussion Paper No. 05-96

\section{Training, Mobility, and Wages: Specific Versus General Human Capital}

Alfred Garloff and Anja Kuckulenz

Download this ZEW Discussion Paper from our ftp server:

ftp://ftp.zew.de/pub/zew-docs/dp/dp0596.pdf

Die Discussion Papers dienen einer möglichst schnellen Verbreitung von neueren Forschungsarbeiten des ZEW. Die Beiträge liegen in alleiniger Verantwortung der Autoren und stellen nicht notwendigerweise die Meinung des ZEW dar.

Discussion Papers are intended to make results of ZEW research promptly available to other economists in order to encourage discussion and suggestions for revisions. The authors are solely responsible for the contents which do not necessarily represent the opinion of the ZEW. 


\section{Nontechnical summary}

This paper considers training, mobility and wages together in order to test whether firm provided training contains a specific component. From a human capital perspective, company training increases the productivity of a match, while from an informational perspective, it improves the knowledge about the quality of a particular job match. From both points of view, training is expected to influence wages, mobility, and wage effects of mobility. Wages contain information about the productivity change or the updated knowledge through training, and so does mobility. We use these interrelations in order to test empirically whether training exhibits mainly general or specific human capital in two particular ways.

First, mobility effects of training can serve as a test whether training contains a firmspecific content but are also interesting in themselves. One reason is that mobility can disturb the investment decision of a firm that decides about providing training. Also, mobility can be efficiency enhancing if bad job matches are dissolved which were detected due to training. Mobility is expected to increase or to remain unchanged if training contains mostly general human capital, while we expect a decreasing mobility when training is mostly specific and not portable between employers. Hence, we use regressions explaining mobility with training participation as explanatory variable as a first test whether training generates general or specific human capital.

As a second empirical test, we consider wage effects of mobility after training. In the light of rent sharing between employers and employees, we expect a positive or zero wage effect of a job change after general training, while specific capital should decrease wages after a job change because a new employer will not reward the specific capital that was useful in the old job. So, wage effects of mobility can be seen to discriminate between those two forms of human capital. To evaluate the wage effects of mobility, we use reported wages directly, but, in addition, we use the judgement of employees whether they profited from their last job change or not, a unique feature of the dataset.

We try to identify a causal effect of training on mobility and on the wage effect of a job change to discriminate between specific and general human capital. As proposed by modern search theory, we take into account that mobility can be endogenous in the wage regression. We also consider endogeneity of the training decision with respect to the mobility decision, since there might be selection into training or mobility.

Summarising, we find empirical evidence in favour of training inhibiting job, firm or occupation specific capital. We find that the probability of being mobile is negatively correlated with the probability of participating in training. Further, we find that both the partial correlation and the wage effects of (exogenous) mobility are negative for the group of training participants, while there is no effect for the group of non-training participants. Furthermore, using a subjective measure whether individuals profited from their last job change or not, we find that participation in training negatively affects the propensity to be better off after a job change. 


\title{
Training, mobility, and wages: specific versus general human capital
}

\author{
Alfred Garloff (ZEW) and \\ Anja Kuckulenz (ZEW)*
}

last updated: 30. November 2005

\begin{abstract}
This paper considers training, mobility decisions and wages together to test for the specificity of human capital contained in continuing training courses. We empirically analyse the relationship between training, mobility and wages in two ways. First, we examine the correlation between training and mobility. In a second step, we consider wage effects of mobility taking training participation into account. First, we find that training participation is negatively correlated with the mobility decision and that training participation decreases the probability of individuals to change the job. Second, we find that wages are lower for job changers for the group of training participants, so wages decrease when trained individuals are mobile. Finally, training participation negatively affects the individuals's subjective valuation of the quality of their last job change. Taken together, these results suggest that there is some specific human capital, which is incorporated into training and lost when moving between jobs.
\end{abstract}

Keywords: training, mobility, wages, search, job matching

JEL-Classification: J31, J41, J62

\footnotetext{
* This work is part of the research project "Formation and Utilization of Differentiated Human Capital" as a part of the research group "Heterogeneous Labour: Positive and Normative Aspects of the Skill Structure of Labour". Support from the German Science Foundation (DFG) is gratefully acknowledged. We would like to thank Irene Bertschek, Christian Dustman, Bernd Fitzenberger, Christian Holzner, Hendrik Jürges, Karsten Kohn, Michael Lechner, Friedhelm Pfeiffer, Steven Portnoy, Ed Vytlacil, Thomas Zwick and the participants of Fitzenberger's doctoral workshop for helpful comments and Jenny Meyer and Iliyan Stankov for helpful research assistance. The usual disclaimer applies. Neither the Bundesinstitut für berufliche Bildung (BIBB), the Institut für Arbeitsmarktund Berufsbildung (IAB) nor the Zentralarchiv (ZA) take any responsibility for the analysis or the interpretation of the data presented here.

Correspondence: Alfred Garloff, Zentrum für Europäische Wirtschaftsforschung (ZEW), P.O. Box 10 34 43, D-68034 Mannheim, Germany, E-mail: garloff@zew.de

Anja Kuckulenz, Zentrum für Europäische Wirtschaftsforschung (ZEW), P.O. Box 1034 43, D-68034 Mannheim, Germany E-mail: kuckulenz@zew.de
} 


\section{Introduction}

Employees can pursue various strategies over their professional life to increase their wage. They can invest in (general or specific) human capital to increase productivity and to be paid accordingly or they can search for better paid jobs (compare Antel (1986)). Training and mobility decisions are not separable, they influence each other and should be analysed simultaneously. Individuals may choose to stay with an employer after (specific) training or they may choose to change the employer after (general) training in order to reap the benefit from training if the old employer keeps part of the training rent.

Firms invest in training activities in order to raise the level of qualification of their work force and to secure strong economic performance. In Germany, about $40 \%$ of the employees obtain training during one year (see Berichtssystem Weiterbildung for data for the year $2000^{1}$. Four years before, in the years 1995/96 the participation in training seems to have been a bit lower with about 7.1 millions members of the German workforce participating in training (see Franz (2003)). Employees aged between 35 and 50 have the highest training participation shares. In 2001, firms in Germany invested almost 17 billion euro in training their workforce (see Weiß (2003)). Hence, firm provided training is considered one of the major post school investments in human capital. Human capital plays an important role in the process of economic growth and individuals' labour market outcomes are linked to their educational attainment. Wage effects of training have been examined and discussed extensively in the literature (see e.g. Pischke (2001), Kuckulenz and Zwick (2003), Buechel and Pannenberg (2004), Juerges and Schneider (2005), and Kuckulenz and Maier (2006) for Germany or Pfeiffer (2001) for a review of microeconometric studies). Labour turnover and training is in the focus of fewer papers. ${ }^{2}$ This paper considers training, mobility and wages together in order to test whether firm provided training inhibits a specific component. From a human capital perspective, company training increases the productivity of a match, while from an informational perspective, it improves the knowledge about the quality of a particular job match. From both points of view, training is expected to have positive effects on wages, and zero or negative effects on mobility, and on wage effects of mobility. Wages contain information about the productivity change or the updated knowledge through training, and so does mobility. We use these interrelations in order to test empirically whether training exhibits mainly general or specific human capital in two particular ways. More specifically, we interpret mobility effects and wage effects of mobility in terms of the specificity of the skills that have been acquired in training

\footnotetext{
${ }^{1}$ Berichtssystem Weiterbildung VIII, Integrierter Gesamtbericht zur Weiterbildungssituation in Deutschland, Bundesministerium für Bildung und Forschung (BMBF), Bonn

${ }^{2}$ Early work that is concerned with specific training and turnover is e.g. Oi (1962) and Deere (1987). Newer work that deals with mobility and training, mostly in the context of frictional labour markets, is e.g. Zweimüller and Winter-Ebmer (2003), Owan (2004), and Adnett, Bougheas, and Georgellis (2004).
} 
courses. 3

The specificity of the contents of training courses is interesting for several reasons. If firm-provided training is general there might exist a hold-up problem, a case of underinvestment. Consider the case, where an employer pays for the (general) training of an employee under the premise that the individual is paid below marginal productivity afterwards. Clearly, the individual has an incentive to renegotiate the wage after the investment, since the investment costs are sunk. If firms anticipate the renegotiation, they will underinvest in training and there is scope for government intervention. Second, the specificity of training investments has been discussed in the context of international differences in labour mobility and unemployment developments (see, e.g., Wasmer (2003)). In this view, the specificity of human capital is central for the adaptability of a system to a changing environment. If, for example, skill-biased technical change accelerates the turbulence in an economy and therefore turnover increases, general skills become more important, since they can be used in many firms. On the other hand, in an economy with a low degree of turnover, a high degree of specificity of skills might guarantee a high labour productivity. Finally, the degree of specificity of company-provided training has also been discussed theoretically and empirically by Krueger and Pischke (1998) and Acemoglu and Pischke (1999) with a focus on the investment in training. They find that under certain conditions, firms are willing to invest in general training and show with German survey data that indeed, part of firmprovided training in Germany is general (see also Booth and Zoega (2001) who provide conditions under which firms provide general training).

The paper is set up as follows. First, we derive two hypotheses in order to empirically test whether training provides participants also with specific skills. Second, we introduce and describe our data set. Third, we line out our estimation strategy. Fourth, we describe our empirical results which are split in three parts. First, we test whether training participation is correlated with mobility and the propensity of switching jobs. Second, controlling for the endogeneity of job mobility we look at the wage effects of job changes for individuals that have participated in training and for individuals that have not. Third, we use the individuals judgement whether their last job change was beneficial to assess the training effect on the wage effect of mobility. Finally, we sum up, conclude and give an outlook.

\section{Derivation of Hypotheses and Estimation Strategy}

To our knowledge there are no theoretical models in the training literature which explicitly show the relationship between training participation, mobility, and wage

\footnotetext{
${ }^{3}$ As argued above, training in specific skills is often observationally equivalent to training that generates information about the quality of a particular match and that is lost upon termination of the match. For an empirical attempt to distinguish between these two kinds of specific capital, see Nagypál (2004).
} 
effects (of mobility). Nevertheless, like previous papers (e.g. Antel (1986) or Spletzer and Loewenstein (1998)), using insights from human capital theory and search theory, we argue that these are interrelated. The coherences between training, mobility, and wages can be used as tests whether training exhibits firm specific human capital.

\subsection{Mobility Effect of Training}

The decision to invest in training on the side of the firm and on the side of the individual is influenced by (expected) mobility. On the one hand, firms are expected to invest in general training of the workforce only if they are able to appropriate part of the returns to the productivity increase. This implies that firms are only then likely to invest in general training if they can restrict workers' mobility afterwards, or if firms expect the mobility of workers to be small 4 One reason for a low labour mobility can be found in the existence of labour market frictions. For example, Acemoglu and Pischke (1999) and Holzner (2005) show that in the case of the existence of frictions and wage bargaining, it can be optimal for firms to invest in general training. 5 On the other hand, mobility might be the desired result (see, e.g., Harris and Felli (2004)). Training might serve screening purposes and might be performed in order to distinguish good from bad matches and sort out the bad ones (e.g., trainee programs might be partly performed for this reason). In this case, mobility would be high after training, because bad matches are wedded out.

If training generates a rent due to higher worker productivity, it depends on how this rent is shared, whether the employer wants to keep the trained worker, or whether the employee has an incentive to stay with the firm. From the employer's point of view this means that as long as there is a rent generated by training, a firm prefers to lay off workers that have not obtained training to those workers which have participated in training. If a worker gains from participation in training and cannot be sure to obtain the same wage mark up from another employer (e.g. due to asymmetric information or specificity of training), the probability for a trained worker to quit and search for a new job will be lower than for a non-trained worker. This implies that the effect of training on the probability of moving between jobs reveals information about the nature of training and rent-sharing.

For training that generates specific human capital, even in a competitive market, there is no unique solution of how to assign the existing rent between employer and employee. The employer might want to pay the individual a wage above the outside option in

\footnotetext{
${ }^{4}$ One reason for this might be that there are complementarities between general and specific human capital (see e.g. Casas-Arce (2005)). In this case, the investment in general capital on the side of the firms induces individuals to invest (more) in specific capital, and thus the mobility of the individuals is reduced.

${ }^{5}$ The investment decision in training in the case of frictions has also been examined by Quercioli (2005), who discusses the decision to invest in specific capital in the context of an equilibrium search model.
} 
order to prevent the individual from changing the employer. It is a reasonable strategy for an employer to provide specific training to workers and to finance this via a low employee turnover through wages below marginal productivity and above the outside option. Another argument for wages above the outside option is that there is a holdup problem, if an individual is able to extract ex-post a part of the (quasi-)rent by renegotiating after training costs are sunk. So, negative mobility effects of training are to be expected in case training imparts specific skills, and in the realistic case where individuals capture a non-zero part of the return to investment in training.

If training provides individuals with general skills, this should not alter the mobility decision in a competitive market. This is because skills are fully paid for in such a world. If, however, the market is not competitive, the effect on mobility is less clear. Mobility may be affected by investments in general skills since market imperfections can turn technologically general into de facto specific skills (see Acemoglu and Pischke (1999)). This is the case, when mobility is constrained or, when the outside wage offer (distribution) does not increase one to one with (the productivity effect of) general skills. It is conceivable that the employing firm does not fully recognise the general skills from training because if the firm has paid for (part of) the training it wants to profit from it and keep (part of) the rent. Then, there could be a mobility increasing effect of general training if other firms are willing to pay for the increased productivity. Hence, for training generating general human capital we expect zero or positive effects on mobility. In the empirical application, we will interpret a zero effect of training on mobility as training that contains only general human capital, although theoretically it is possible that firms pay individuals their outside option in the case of specific training.

The following proposition summarizes the above arguments.

Proposition 1 If training contains only general human capital, then the mobility decision of workers is unaffected if workers are paid their outside option (the competitive case) or the mobility decision is positively affected when workers are paid below their outside option (the rent sharing case). If training contains a specific component, the mobility effect is expected to be negative since in general individuals are paid above their outside option.

\section{Estimation Strategy}

We assume that the error term in the decision of being mobile is normally distributed and therefore model the mobility decision as a Probit model. According to this model, the probability of changing the employer depends on a vector $X$, which in our case contains individual characteristics, job characteristics, firm characteristics and a constant, 6

\footnotetext{
${ }^{6}$ Notice that both firm and job characteristics refer to the current job, i.e. the job an individual changes to. We are aware that this is a critical assumption, but unfortunately, we do not have data on the previous job. Therefore, we only include these characteristics as controls rather than giving an interpretation as (causal) effects on mobility. For the standard interpretation as coefficient we would
} 
on a parameter vector $\beta$ and on the unobservable error term $\epsilon$.

$$
J C^{*}=P(J C=1 \mid X, T)+\epsilon=\Phi\left(\beta^{\prime} X+\gamma T\right)+\epsilon
$$

$J C=1$ means an job change, $T$ is training participation, $\gamma$ is the effect of training on the probability to change the job, $J C^{*}$ can take the values zero and one.

The model is estimated by maximising the likelihood function as it is standard with binary choice models, where the likelihood function is the product of the cumulated density function (of the normal distribution) for job changers and of the survivor for job stayers.

Note however, that training might be endogenous with respect to mobility, for example in the case of specialisation in search or in training as suggested in Antel (1986). In order to generate exogenous variation of the probability of training participation, we use the training intensity by industry, estimated from an earlier wave of the dataset in use.7 It is reasonable to assume (and can be shown empirically) that the training intensity in 1991/1992 is uncorrelated with the wage 1998/1999, while inertia and structural differences across industries suggest that it is (significantly) correlated with training participation in 1999 (see table 8). Since it is easier to interpret the results, although we estimate an Instrumental Variable Probit, too, we display the results for a linear Instrumental Variable model.$^{8}$ Further, we do not use the instruments directly in the IV procedure, but we use the predicted values from a first stage Probit model for training participation as instrument, since this is the optimal instrument if the model is correctly specified and since that procedure has some nice robustness properties (see Wooldridge (2002), p. 623ff.). $]^{9}$ More precisely, we estimate a Probit model for training participation including all covariates from the job change equation plus the external identifying variable (training intensity in 1991 by industry).10 The predicted value from this model is then used as instrument in a standard IV approach. To be a bit

need to assume that job and firm characteristics are unaffected by the job change, which is a strong assumption. In the empirical application, especially sectors have a strong partial correlation with mobility, which we do not want to omit. So, basically the coefficient interpretation requires that the job change remains in the same sector.

${ }^{7}$ Note that the common use of industry dummies and the training intensity by industry is not a contradiction, since the training intensity is on a more disaggregated level.

${ }^{8}$ Instrumental Variable methods for Probit models are discussed for example in Newey (1987). Results from an Instrumental Variable Probit estimation are available upon request. They do not differ in sign and significance from the results we display here.

${ }^{9}$ In fact, we only need the linear projection of training on the set of covariates and the predicted participation probability of the (potentially) misspecified model to depend actually on the participation probability.

${ }^{10}$ Recognise that in a strict sense, we do not need exclusion restrictions. Although theoretically, the functional form identifies the effect of training, in empirical work it is very common to use additional exclusion restrictions to circumvent problems with multicollinearity. 
more formal:

$$
J C^{*}=\delta^{\prime} X+\alpha T+u
$$

is the (linear probability) model to be estimated by 2SLS, where $X$ contains a constant, $T$ is training participation as before and $u$ is an error term. Again, $J C^{*}$ takes the values zero or one. The instrument is the predicted probability for participating in training $\hat{P}(T=1 \mid X, Z)=\Phi\left(\hat{\zeta}^{\prime} Z+\hat{\lambda}^{\prime} X\right)$ deduced from a Probit model $P(T=1 \mid X, Z)=$ $\Phi\left(\zeta^{\prime} Z+\lambda^{\prime} X\right)$.

When estimating the model as 2SLS, we use a robust estimator for the variancecovariance matrix, since standard errors are heteroscedastic by construction, when estimating a binary response model as linear regression model.

\subsection{Wage Effect of Mobility}

Closely linked to the question of mobility of individuals after training participation are wage effects of mobility if individuals have participated in training before. This is interesting because the wage effect of a job change to a new firm reveals information about the skills of an individual which are transferable across firms. Discussing the wage effect of mobility after training, human capital theory predicts wage losses if training has provided the individual with specific skills. In the case of general training, under rent sharing, individuals might be paid below their outside option. In this case, there could be wage gains from a job change. For this to be true, it does not matter whether mobility is endogenous or exogenous.11

Following Loewenstein and Spletzer (2000), we interpret the empirical effect of training on wages as an indicator for the degree of specificity of the training obtained. We test whether workers who change their job after training are paid less than those workers which do not change their job after training. A "high" wage of job movers after training may indicate that employers share costs of and returns to general training and that full gains from training investments can be reaped by employees at a new employer. A "low" wage of job movers, in contrast, might indicate that firm (job) specific skills are lost and productivity in the new firm is lower (see also Spletzer and Loewenstein (1998), Pannenberg (1995), Booth and Bryan (2002) and Gerfin (2004). Hence, if training provides individuals with specific skills and if returns are shared, a job change after training is predicted to have a negative effect on wages. There is no theoretical prediction for a job change without training. If a job change also invokes a negative coefficient, then the effect of a job change after training is bigger in absolute value. In case of general skills and the presence of rent sharing between employer and employee,

\footnotetext{
${ }^{11}$ From this point of view, individuals receive their outside option if they change jobs, independently of whether job-to-job transitions are exogenous or endogenous.
} 
the predicted coefficient of a job change after training is positive or zero, because it is not certain whether the part of the rent which is captured by the firm providing training is also obtained by a new employer. Therefore, estimating the coefficient of job change in a wage regression after participating in training gives a hint whether training is mainly firm specific or general.

The following proposition summarizes the arguments.

Proposition 2 If training provides individuals with general skills, a job change after training implies no wage change (in the case of a competitive market) or a positive wage change if the firm captures a part of the rent generated by training (the rent sharing case). If training also contains specific human capital, we expect the wage change caused by job mobility to be negative since, in general, the worker will be able to extract a part of the rent generated by specific training.

\section{Estimation Strategy}

We estimate a Mincer equation and interpret the coefficient of job change after training. In the regression we control for a variety of demographic variables, including the variables of an enhanced Mincer equation, experience and tenure and the square of both. We treat mobility effects for the group of training participants and individuals that have not participated in training separately, because training participants and non-training participants might be systematically different.

More formally, for training participants we have

$$
\ln Y=\beta_{1}^{\prime} X+\beta_{2} J C T+e,
$$

$\ln Y$ are $\log$ earnings, $X$ contains schooling, experience (squared), tenure (squared) and lots of demographic variables, but also firm, job and industry characteristics and a constant and $\beta_{1}^{\prime}$ is the coefficient vector. $\beta_{2}$ is the influence of a job change after training $(J C T)$ on earnings and $e$ represents an unobservable error term. For non-participants we estimate a similar equation.

There are some remarks to make, however. The above analysis assumes that in order to consistently estimate the wage effect of job-to-job transitions after training, job movers and stayers are similar otherwise. This is not sufficient, however, because the decision to change a job depends on various factors such as previous training. Mobility is endogenous if the mobility decision is taken because of the outside wage, while mobility is exogenous when mobility takes place for reasons that do not depend on the outside wage. It is not problematic to use exogenous mobility in a wage regression, while the use of endogenous mobility leads to a bias. 
Notice that if individuals are paid their outside option, mobility cannot be endogenous. If individuals are not paid their outside option and if the decision to change a job is taken as assumed in search theory, there is an endogeneity problem. To see this, recognise that from this point of view, the decision to change a job is made on the basis of the current wage and outside wage offers that arrive at irregular time intervals and that are random draws from a wage offer distribution. Hence, wage and job mobility are determined simultaneously.

Still, involuntary job mobility is not enough to guarantee exogeneity of the job change variable with respect to the wage, since firms might lay off people because of wages being too high. Using information whether the partner is working and whether there are children in schooling age helps us to identify the wage effect of exogenous and involuntary mobility. ${ }^{12}$ We base our analysis of wage effects of job moves both upon a comparison of stayers and movers accounting for endogeneity (i.e. a 2SLS approach) and upon the direct appraisal of the individuals whether the job change ameliorated their professional position or not ${ }^{13}$ For all estimated models we choose a robust variancecovariance estimator, since wages are in general assumed to be heteroscedastic 14

An alternative approach to evaluate the job change effect for training participants and non-training participants is to use the direct subjective judgement of individuals whether they profited from their last job change or not and to explain this dummy variable by participation in training. Clearly, we restrict our attention to job changers in this case. Note that there is no reason to suppose an endogeneity problem in this case, since we restrict our attention to job changers. There would be a problem of endogeneity if the training participation decision depended on the perceived returns to future mobility.

\section{Data and Descriptive Evidence}

We use a rich data set, compiled from a representative sample of 0.1 percent of all individuals employed in Germany. The BIBB/IAB "Qualification and career survey" ("Berufliche Qualifikation und Erwerbsarbeit") is jointly ascertained by the Institute for Employment Research (Institut für Arbeitsmarkt- und Berufsforschung, IAB Nürnberg) and the Federal Institute for Vocational Education and Training (Bundesinstitut für Berufsbildung, BIBB Berlin). The survey is implemented every seven years, but it

\footnotetext{
${ }^{12}$ Following Dustmann and Meghir (2005) and for comparison reasons, for training participants, we have also used firm closure as instrument, yielding very similar results.

${ }^{13}$ For the same reason why a job change is endogenous in a wage regression, tenure is also endogenous. By including information on the number of previous employers, however, we can account for a source of endogeneity in tenure.

${ }^{14}$ Note that the selection in training is clearly endogenous with respect to the wage. Therefore, analogous to Wolf and Zwick (2002) we also estimate the model including (Heckman) correction terms from a Probit model for training participation. Since the results are virtually unaffected and since the coefficients are even not always significant, we display the results without Heckman correction.
} 
is not a panel. Hence, we cannot observe and compare wages before and after training and/or job changes directly. We will use the latest wave available, which is from the survey in 1998/99. It comprises more than 34.000 employees ${ }^{15}$ The cross-section data on employed individuals in Germany contain detailed information on the qualification and the professional career of each individual, the organisational and technological environment of jobs, and the qualifications demanded for jobs. Furthermore, information about the employer and some personal attributes are included. Specifically, we use the following variables (see also table 6 in the appendix for the complete list with detailed descriptions and table 7 for a German translation of selected variables):

- The wage variable is log midpoints of earnings from 18 categories. We use midpoints of the intervals in the same way other authors have done it (see e.g Kuckulenz and Zwick (2003) or Pfeiffer and Reize (2001))

- The first key variable is participation in training during the last five years. The first question is whether the individual participated in courses or seminars in this time period. The second inquiry is on the year the last training course took place. ${ }^{17}$ By combining both questions, we obtain dummies for participation in training in either one specific year or in several years. Since we know when training took place, we can use this information later to distinguish between training before or after job changes. An important measurement problem of our training variables is that they do not include information on the length and costs of the training attended. Hence, we cannot control for training intensity when estimating effects on wage and mobility.

- The second key variable is job change. We cannot directly observe this variable. To construct the job change variable and the date of job change, we use information on the number of employers together with the question since when one works for the actual employer. It is also asked why people have changed the employer and whether they profited from the job change. We use the judgement

\footnotetext{
${ }^{15}$ To discuss interrelations between training, mobility and wages, it would be optimal to use a large panel data set where individuals are observed before and after training and job changes. For Germany, the Socioeconomic Panel (GSOEP) is the only available panel data set including this information. It also provides direct information on whether training is general or firm specific. For our purpose, the GSOEP contains too little observations, however. For example, only 4 individuals in the data set took part in on-the-job training in 1998 and changed their job afterwards (own calculations from GSOEP 2000). This means that thorough empirical testing of our hypotheses is impossible.

${ }^{16}$ The first category includes all earnings below $600 \mathrm{DM}$, the second includes earnings from 600 DM until 1,000 DM. The following categories comprise earnings intervals of 500 DM up to 6,000 DM. From 6,000 DM to earnings of $10,000 \mathrm{DM}$, the intervals are in steps of $1,000 \mathrm{DM}$. The next category comprises earnings from 10,000 DM until 15,000 DM and the last category includes all earnings of 15,000 DM, and above. Most earnings can be found in the categories between 3,000 DM and 5,000 DM, see table 6 in the appendix for descriptive statistics.

${ }^{17}$ There are two questions on the participation in continuing training. First, "Please think about the last five years, i.e. the time from 1994 until today. Did you attend during that time any seminars or courses which serve your continuous process of education?" Second, "In which year did the course take place?"
} 
of the individual whether it has profited from the employer change directly as endogenous variable, in order to assess the effect of training on the probability to change the job. ${ }^{18}$

- To control for selection into training in the mobility equation, we tried several identifying variables. The results are similar for most of them. Based on theoretical arguments, finally, we choose the training intensity by industry, estimated from an earlier wave (1991/1992) of the BIBB/IAB-survey. Using imputed data from the Continuing Vocational Training Survey (CVTS 2000) about sectoral shares of firms and shares of firms by employment size that include continuous training in their collective bargaining agreement, yields quite similar results.19

- As discussed above, a job change is partly endogenous in the wage regression. In principal, there is some nice information on exogenous job change in the data set, which we can use as instruments, namely firm closure, and occupational changes for health or family reason..$^{20}$ In the wage regression, unfortunately, these instruments do not generate enough variation or are surprisingly not exogenous. Hence, we use two further variables as instruments which cause variation in the job change equation but not in the wage equation. First, we use information on the fact whether the employed individual has a partner that is employed, too. It is reasonable to assume (and is empirically shown) that this variable is not related to an individuals earnings, while it is very realistic to think that the individual is more bound to a region, so that there are less job offers and therefore less employer changes. As a second variable, we use a dummy whether the individual has children between 6 and 17 years. To see why, in the wage equation we control for the number of children, since this is (significantly) correlated with the wage. But, we think (and show) that whether the children are in schooling age or not does affect mobility while it should (and empirically does) not affect earnings.

- Further explanatory variables are those found in the Mincer-equation, i.e. work experience (and its square) ${ }^{21}$ job tenure (and its square), former unemployment, and dummies for the highest educational achievement. ${ }^{22}$

- Along with these standard variables, we also include some dummies capturing the professional status, such as blue-collar or white-collar worker, civil servant or

\footnotetext{
${ }^{18}$ Note that the job change variable not only includes direct job-to-job transitions. It also includes for example individuals that transit through unemployment, before working for the next employer. For comparison reasons, we have constructed a job change variable for individuals that are never unemployed before the interview. The results do not differ by much, though.

${ }^{19}$ The CVTS data is from 1999 and therefore fits well to the BIBB/IAB data set.

${ }^{20}$ In a former version of the paper we have estimated training participation equations using job changes as an explanatory variable and using the above instruments. In this estimation these instruments worked quite nicely.

${ }^{21}$ We know when the individual started his or her first job and we include dummies for discontinuation such as unemployment.

${ }^{22}$ In Germany, the highest schooling degree is more informative for the level of education than years of schooling (see Georgellis and Lange (1997)).
} 
different sophistication levels of tasks.

- In addition, we use the following job characteristics: computer use, profit-sharing, bonus payments, overtime work, whether a job is temporary, and main job contents. These variables allow us to control a large part of the individual heterogeneity between the employees. ${ }^{23}$ Some of these variables (for example, overtime work) can be interpreted as indicators for intrinsic motivation.

- Additional control variables explaining earnings are personal attributes. We include dummies for females, having children, and German nationality.

- Finally, we also control for the firm size and we include a dummy indicating whether the individual lives in East or West Germany because earnings as well as costs of living still differ between the two regions.

Hours worked vary widely in the data and we found a number of implausibly high reported values. Therefore, we only use full-time ${ }^{24}$ employees.

During the last five years, 44 percent of the employees attended at least one continuing vocational training course or seminar. This proves that for a large part of the employees, training takes place. Of those workers who participated, almost 50 percent participated last year (1998), 20 percent participated 2 years ago in the last training course or seminar, and for the remaining employees, the last training took place more than 2 years ago. When looking at all employees, around 70 percent have changed the job at least once, i.e. they worked at least for 2 different employers. During the previous year, almost 12 percent of the employees changed their job.25 Several reasons why the last job ended are distinguished in our data set. In particular, 66 percent of the individuals state that it was their own desire to leave the former employer, 12 percent had to leave because the firm wanted them to, 7 percent left because their fixed term contract ended and 15 percent state that the firm went bankrupt. In their new job, 70 percent of the job changers are happier than before, for 21 percent the situation is unchanged, and 9 percent of the individuals state that they are unhappier in the new job than they were in the old job. Not surprisingly, out of those individuals who change the job because it was their own desire to do so, 80 percent are happier in their new job. Likewise, 17 percent of those individuals that did not want to leave the firm state that the situation in the new job is worse than in the old one. Combining training and mobility, it is interesting to know whether individuals are less likely to change jobs after they participated in training. Given the descriptive statistics, this seems to be

\footnotetext{
${ }^{23}$ Some of these variables may also be endogenous in the earnings equation. We do not control this, however, because the variables mainly serve as control variables for employee heterogeneity.

${ }^{24}$ We include only employees working 30 hours and above per week. We also use a dummy for working overtime in order to take hours worked into account.

${ }^{25}$ The number of job changes is somewhat higher in our data set compared to other German data sets (see e.g. Fitzenberger and Garloff (2005)). The reason is that we do not observe job-to-job transitions directly and hence, some individuals which enter a new job after staying at home or after being unemployed for a while are also included as job changers.
} 
the case. After 1994, 23 percent of the employees have changed their job but only 11 percent of those which took part in training during this time period changed their job afterwards.

\section{Empirical Results}

\subsection{Mobility Effect of Training}

Looking at table 1, there is a negative partial correlation between training and mobility as individuals that have participated in training before 1997, change jobs less often after 1997 than otherwise comparable individuals. If we take into account that participation in training might be endogenous with respect to the mobility decision, the effect of training, instrumented by the training intensity by industries from the last wave of the BIBB/IAB survey, increases in absolute value (compare training coefficient in tables 1 and 2). ${ }^{26}$ If an individual has more than two previous employers, this increases the probability of a job change and points to the fact that the number of previous job changes is an important predictor for future job changes. This is in accordance with specialisation in search or specific training as proposed by Antel (1986) or with the hobo syndrome by Ghiselli (1974), where employees have an intrinsic motivation to change jobs after some years.

Interpreting and comparing the point estimates of the two approaches, means that exogenous training participation has, on average, a bigger negative partial correlation with labour mobility than training participation in the population. That is, if somebody is admitted exogenously to training, he or she is more likely to stay in the firm. This is counterintuitive and contradicts the Antel (1986) story where people are assumed to specialise in training or search.

Because of this counterintuitive result, we perform a Durbin-Wu-Hausman test for exogeneity of training given the instruments. We fail to reject exogeneity for the instruments in use. From this we conclude that we should not overinterpret the IV results and we prefer the Probit results. Summarising, the results point to a negative effect of training on mobility. This is consistent with training inhibiting specific capital for the employer or the match which would be lost upon job change.

\footnotetext{
${ }^{26}$ To see that there might be an endogeneity problem, recognise that an individual who wants to change the employer has no incentive to invest in employer specific human capital. The number of observations slightly differs between the two approaches, since there are some differences in the industry classification between the two waves. The first stage results are printed in the appendix (see table 8).
} 
Table 1: Does training affect labour mobility?

\begin{tabular}{|c|c|c|}
\hline Variable & Coefficient & (Std. Err.) \\
\hline Training before 1997 & $-0.092^{*}$ & $(0.046)$ \\
\hline \multicolumn{3}{|c|}{ Individual Characteristics } \\
\hline More than two Previous Employers & $0.555^{* *}$ & $(0.040)$ \\
\hline Professional Experience & $-0.051^{* *}$ & $(0.008)$ \\
\hline Professional Experience Squared & $0.001^{* *}$ & $(0.000)$ \\
\hline Unemployment & $0.497^{* *}$ & $(0.035)$ \\
\hline Age & $-0.040^{* *}$ & $(0.006)$ \\
\hline Lower Secondary School & -0.003 & $(0.044)$ \\
\hline Entrance to University for Applied Sciences & 0.055 & $(0.083)$ \\
\hline High School Diploma & 0.116 & $(0.071)$ \\
\hline Without School Leaving Certificate & -0.070 & $(0.117)$ \\
\hline Without Professional Degree & $-0.131^{*}$ & $(0.054)$ \\
\hline University for Applied Sciences & 0.090 & $(0.092)$ \\
\hline University & $0.231^{*}$ & $(0.092)$ \\
\hline
\end{tabular}

\section{Other Controls}

Not Married, East Germany, Household Size (3), Sex, Children, Children's Age (3), Full-Time Vocational School, Master Craftsman, Temporary Work, Computer Work Station, Size of Firm (6), White-Collar Worker, Economic Sectors (4), Overtime, Profit-Sharing, Incentive Wage, Working Hours, Partner Employed, Firm Failure, Occupational Change (2), Restructuring, Need for Training

\begin{tabular}{|c|c|}
\hline Intercept & $(0.203)$ \\
\hline $\mathrm{N}$ & 9335 \\
\hline Log-likelihood & -3721.979 \\
\hline$\chi_{(48)}^{2}$ & 1640.665 \\
\hline
\end{tabular}


Table 2: IV estimates of the effect of training on job mobility

\begin{tabular}{|c|c|c|}
\hline Variable & Coefficient & (Std. Err.) \\
\hline Training before 1997 & $-0.510^{*}$ & $(0.251)$ \\
\hline \multicolumn{3}{|c|}{ Individual Characteristics } \\
\hline More than two Previous Employers & $0.126^{* *}$ & $(0.012)$ \\
\hline Professional Experience & $-0.017^{* *}$ & $(0.002)$ \\
\hline Professional Experience Squared & $0.000^{* *}$ & $(0.000)$ \\
\hline Unemployment & $0.128^{* *}$ & $(0.010)$ \\
\hline Age & $-0.009^{* *}$ & $(0.001)$ \\
\hline Lower Secondary School & $-0.025^{\dagger}$ & $(0.015)$ \\
\hline Entrance to University for Applied Sciences & -0.003 & $(0.023)$ \\
\hline High School Diploma & 0.021 & $(0.021)$ \\
\hline Without School Leaving Certificate & -0.030 & $(0.032)$ \\
\hline Without Professional Degree & $-0.039^{* *}$ & $(0.015)$ \\
\hline University for Applied Sciences & 0.016 & $(0.025)$ \\
\hline University & 0.036 & $(0.027)$ \\
\hline
\end{tabular}

\section{Other Controls}

Not Married, East Germany, Household Size (3), Sex, Children, Children's Age (3), Full-Time Vocational School, Master Craftsman, Temporary Work, Computer Work Station, Size of Firm (6), White-Collar Worker, Economic Sectors (4), Overtime, Profit-Sharing, Incentive Wage, Working Hours, Partner Employed, Firm Failure, Occupational Change (2), Restructuring, Need for Training

\begin{tabular}{|c|c|}
\hline Intercept & $0.487^{* *}$ \\
\hline $\mathrm{N}$ & 8915 \\
\hline $\mathrm{R}^{2}$ & 0.022 \\
\hline $\mathrm{F}_{(48,8866)}$ & 36.879 \\
\hline
\end{tabular}




\subsection{Wage Effect of Mobility}

As a second empirical test, we consider wage effects of mobility after training. In the light of rent sharing between employers and employees, we expect a positive or zero wage effect of a job change after general training, while specific capital should decrease wages after a job change because a new employer will not reward the specific capital that was useful in the old job. As expected after the first test result, we find here that both estimates, the partial correlation as well as the wage effect of an employer change, for the subgroup of training participants are negative (see tables 3 to (4). Both least squares and IV-methods yield a significant negative coefficient and the effect increases in magnitude when endogeneity of the employer change is taken into account ${ }^{27}$ An exogenous job change is associated with a higher wage loss than an endogenous job change, where individuals decide voluntarily to change the job on the basis of a wage comparison, as we would expect. Clearly, in the individuals' decision to change a job the wage that an alternative job would pay, plays a crucial role. This is confirmed by our results. The fact that both endogenous and exogenous employer changes yield a wage loss for the group of training participants was predicted from the hypothesis that training incorporates a substantial share of employer or job specific capital. This confirms the results from the previous section. Recognise however, that the difference between the IV estimator and the OLS estimator implies that there is endogenous mobility, pointing to the fact that a simple human capital interpretation is not admissible.

Since search theory predicts a negative effect of job changes also in the absence of specific capital, ${ }^{28}$ we also consider the population of non-training participants and wage effects of job changes in this group (see tables 10 to 12 in the appendix). The correlation between the job change variable and the wage is not significantly different from zero. Taking endogeneity of employer changes into account and using a dummy variable for whether the partner is employed and for the age of children as instruments, again yields an insignificant coefficient for job change. Summarising, (exogenous) job changes seem to have no significant effect on wages for the group of non-training participants (this confirms the results in Pannenberg (1995). This finding is consistent with individuals being paid their outside option on average.

Finally, we use information, where individuals judge themselves whether they profited from their last job change (see table 5). A Probit model for the group of job changers with training (before the job change) as explanatory variable yields a negative coefficient, which is significant. Note that a specialisation in training or search does not predict endogeneity of training in this equation, because it predicts a correlation between job change and training but not a correlation between the wage change through

\footnotetext{
${ }^{27}$ Again, the number of observations differs because of some missing values for the instruments. The first stage estimation can be found in the appendix (see table 9).

${ }^{28}$ This is the so called wage ladder effect, the effect from self-selection in higher paying jobs.
} 
Table 3: Participants in training: Correlation of job change and wages

\begin{tabular}{lcc}
\hline \hline \multicolumn{1}{c}{ Variable } & Coefficient & (Std. Err.) \\
\hline \multicolumn{1}{c}{ Individual Characteristics } \\
\hline More than two Previous Employers & $-0.028^{\dagger}$ & $(0.016)$ \\
Professional Experience & 0.004 & $(0.010)$ \\
Professional Experience Squared & 0.003 & $(0.002)$ \\
Company Tenure & $0.000^{* *}$ & $(0.000)$ \\
Company Tenure Squared & $0.007^{* *}$ & $(0.002)$ \\
Unemployment & 0.000 & $(0.000)$ \\
Age & $-0.063^{* *}$ & $(0.010)$ \\
Lower Secondary School & $0.008^{* *}$ & $(0.002)$ \\
Entrance to University for Applied Sciences & $0.069^{* *}$ & $(0.013)$ \\
High School Diploma & $0.063^{* *}$ & $(0.016)$ \\
Without School Leaving Certificate & -0.004 & $(0.018)$ \\
Without Professional Degree & $-0.087^{* *}$ & $(0.036)$ \\
University for Applied Sciences & $0.098^{* *}$ & $(0.020)$ \\
University & $0.225^{* *}$ & $(0.021)$ \\
\hline
\end{tabular}

\section{Other Controls}

Not Married, Foreigner, Handicapped, East Germany, Household Size (3), Sex, Children, Full-Time Vocational School, Master Craftsman, Temporary Work, Computer Work Station, Size of Firm (6), Professional Position (4), Economic Sectors (47), Overtime, Profit-Sharing, Incentive Wage, Working Hours

\begin{tabular}{|c|c|}
\hline Intercept & $7.215^{* *}$ \\
\hline$\overline{\mathrm{N}}$ & 4552 \\
\hline $\mathrm{R}^{2}$ & 0.546 \\
\hline $\mathrm{F}_{(85,4466)}$ & 65.048 \\
\hline
\end{tabular}

a job change and training ${ }^{29}$ We conclude that training participation seems to have a negative effect on the propensity to improve upon the perceived position through a job-to-job change. In our view, this is the most convincing test because it is the most direct evidence on the specifity of training substance. It supports our result that training inhibits specific human capital, which is lost when switching to a different job.

\section{Conclusion}

In this paper we analysed the effects of training on mobility and the effect of training on the wage effects of mobility. We used these results to interpret the degree of specificity

\footnotetext{
${ }^{29}$ In addition, we found in the mobility estimation that the null hypothesis of exogeneity could not be rejected, so that this sort of endogeneity is probably not present.
} 
Table 4: Participants in training: IV estimates of the effect of a job change on wages

\begin{tabular}{lcc}
\hline \hline \multicolumn{1}{c}{ Variable } & Coefficient & (Std. Err.) \\
\hline \multicolumn{1}{c}{ Individual Characteristics } \\
\hline More than two Previous Employers & $-0.077^{*}$ & $(0.035)$ \\
Professional Experience & 0.004 & $(0.010)$ \\
Professional Experience Squared & 0.004 & $(0.002)$ \\
Company Tenure & $0.000^{* *}$ & $(0.000)$ \\
Company Tenure Squared & $0.005^{\dagger}$ & $(0.003)$ \\
Unemployment & 0.000 & $(0.000)$ \\
Age & $-0.062^{* *}$ & $(0.010)$ \\
Lower Secondary School & $0.009^{* *}$ & $(0.002)$ \\
Entrance to University for Applied Sciences & $0.063^{* *}$ & $(0.013)$ \\
High School Diploma & $0.062^{* *}$ & $(0.016)$ \\
Without School Leaving Certificate & 0.003 & $(0.017)$ \\
Without Professional Degree & $-0.077^{* *}$ & $(0.029)$ \\
University for Applied Sciences & $0.092^{* *}$ & $(0.020)$ \\
University & $0.215^{* *}$ & $(0.021)$ \\
\hline
\end{tabular}

\section{Other Controls}

Not Married, Foreigner, Handicapped, East Germany, Household Size (3), Sex, Children, Full-Time Vocational School, Master Craftsman, Temporary Work, Computer Work Station, Size of Firm (6), WhiteCollar Worker, Economic Sectors (47), Overtime, Profit-Sharing, Incentive Wage, Working Hours, Firm Failure, Occupational Change (2)

\begin{tabular}{|c|c|}
\hline Intercept & $7.194^{* *}$ \\
\hline $\mathrm{N}$ & 4488 \\
\hline $\mathrm{R}^{2}$ & 0.55 \\
\hline $\mathrm{F}_{(87,4400)}$ & 64.166 \\
\hline
\end{tabular}

of training. All in all, the results suggest that there are both a negative correlation of training with job change and a negative effect of training on job change. As far as the wage is concerned, there are stable causal negative effects of both employer and occupational changes on wages for the group of training participants. For the group of non-training participants there is no significant relationship between a job change and wages, thereby suggesting that individuals are on average paid their outside option. This suggests that training indeed has a specific component which is lost for exogenous and endogenous, for voluntary and involuntary job changes. Note, that this is also consistent with the idea that training generates information on the quality of a particular match.

Using the direct judgement from job changers whether they profited from job change or not, seems to bear the best information however, since it is easier to find the adequate control group. We can easily take the group of individuals that has profited from a 
Table 5: Effect of training on subjective change in the position after an employer change

\begin{tabular}{|c|c|c|}
\hline$\overline{\text { Variable }}$ & Coefficient & $\overline{~(S t d . ~ E r r .) ~}$ \\
\hline Occupational Change after Training & $-0.133^{\dagger}$ & $(0.074)$ \\
\hline \multicolumn{3}{|c|}{ Individual Characteristics } \\
\hline More than two Previous Employers & $0.169^{*}$ & $(0.076)$ \\
\hline Professional Experience & $-0.033^{*}$ & $(0.014)$ \\
\hline Professional Experience Squared & 0.000 & $(0.000)$ \\
\hline Company Tenure & -0.020 & $(0.105)$ \\
\hline Company Tenure Squared & 0.017 & $(0.023)$ \\
\hline Unemployment & $-0.398^{* *}$ & $(0.068)$ \\
\hline Age & -0.007 & $(0.010)$ \\
\hline Lower Secondary School & 0.074 & $(0.075)$ \\
\hline Entrance to University for Applied Sciences & -0.040 & $(0.145)$ \\
\hline High School Diploma & -0.069 & $(0.122)$ \\
\hline Without School Leaving Certificate & -0.007 & $(0.193)$ \\
\hline Without Professional Degree & 0.148 & $(0.097)$ \\
\hline University for Applied Sciences & -0.145 & $(0.150)$ \\
\hline University & $-0.300^{*}$ & $(0.153)$ \\
\hline
\end{tabular}

\section{Other Controls}

Not Married, Foreigner, Handicapped, East Germany, Household Size (3), Children, Sex, Full-Time Vocational School, Master Craftsman, Temporary Work, Computer Work Station, Size of Firm (6), WhiteCollar Worker, Economic Sectors (47), Overtime, Profit-Sharing, Incentive Wage, Working Hours, Partner Employed, Occupational Change (2), Restructuring, Need for Training

\begin{tabular}{|c|c|}
\hline Intercept & $(0.836)$ \\
\hline $\mathrm{N}$ & 3260 \\
\hline Log-likelihood & -1204.629 \\
\hline$\chi_{(85)}^{2}$ & 273.812 \\
\hline
\end{tabular}

job change and compare training participants and non-participants. Here, we find that training reduces the probability of an amelioration through a job change. Thus, from this view, too, training can be interpreted as incorporating employer (job) specific human capital.

Summing up, the evidence points to the fact that most training seems to generate some specific capital. This specific capital can be existent as a real productivity increase in the respective firm or, equivalently, as information about the quality of the match. Our findings are somewhat in contradiction to recent findings that most training is general, but it may well be the case that training provides both, firm specific and general human capital. Future work should try to capture better the heterogeneity of training and distinguish between various kinds of training when testing for specificity. 


\section{References}

Acemoglu, D., and J.-S. Pischke (1999): The Structure of Wages and Investment in General Training. Journal of Political Economy, 107, pp. 539-572.

Adnett, N., S. Bougheas, and Y. Georgellis (2004): On the Trade-Off Between WorkRelated Training and Labor Mobility: The Role of Firing and Exit Costs. Journal of Economics, 82(1), pp. 49-70.

Antel, J. J. (1986): Human Capital Investment Specialization and the Wage Effect of Voluntary Labor Mobility. Review of Economics and Statistics, 68, pp. 477-483.

Booth, A. L., and M. L. Bryan (2002): Who Pays for General Training? Testing Some Predictions of Human Capital Theory. Unpublished Manuscript, University of Essex, Colchester.

Booth, A. L., and G. Zoega (2001): Is Wage Compression a Necessary Condition for Firm-Financed General Training?. Discussion Paper No. 2845, CEPR, London.

Buechel, F., and M. Pannenberg (2004): Berufliche Weiterbildung in West- und Ostdeutschland: Teilnehmer, Struktur und individueller Ertrag. Zeitschrift für Arbeitsmarktforschung, 37 (2), pp. 73-126.

Casas-Arce, P. (2005): Firm Provision of General Training and Specific Human Capital Acquisition. Unpublished Manuscript, University of Oxford, Oxford.

Deere, D. R. (1987): Labor Turnover, Job-Specific Skills, and Efficiency in a Search Model. The Quarterly Journal of Economics, 102(4), pp. 815-834.

Dustmann, C., and C. Meghir (2005): Wages, Experience and Seniority. Review of Economic Studies, 72, pp. 77-108.

Fitzenberger, B., and A. Garloff (2005): Descriptive Evidence on Labour Market Transitions and the Wage Structure for Germany. Unpublished Manuscript, Centre of European Economic Research (ZEW), Mannheim.

Franz, W. (2003): Arbeitsmarktökonomik. Berlin et al.: Springer-Verlag, fifth, completely revised edn.

Georgellis, Y., and T. Lange (1997): The Effect of Further Training on Wage Growth in West Germany, 1984-1992. Scottish Journal of Political Economy, 44(2), pp. 165181.

Gerfin, M. (2004): Firm-Sponsored General Training in Frictional Labour Markets: An Empirical Analysis for Switzerland. Discussion Paper No. 1077, IZA, Bonn.

Ghiselli, E. (1974): Some perspectives for industrial psychology. American Psychologist, pp. $80-87$.

Harris, C., and L. Felli (2004): Firm-Specific Training. Discussion Paper No. 4580, CEPR, London. 
Holzner, C. (2005): Search Frictions, Credit Constraints and Firm Financed General Training. Working Paper No.6, Ifo, Munich.

Juerges, H., and K. Schneider (2005): Dynamische Lohneffekte berufliche Weiterbildung - Eine Längsschnittanalyse mit den Daten des SOEP. Discussion Paper No. 92, MEA, Mannheim.

Krueger, A. B., and J.-S. Pischke (1998): Observations and Conjectures on the U.S. Employment Miracle. In: Third Public GAAC Symposium: Labor Markets in the USA and Germany, pp. 99-126. Bonn: German-American Academic Council.

Kuckulenz, A., and M. Maier (2006): Heterogeneous Returns to Training. An Analysis with German Data Using Local Instrumental Variables. Jahrbücher für Nationalökonomie und Statistik, 226(2).

Kuckulenz, A., and T. Zwick (2003): The Impact of Training on Earnings - Differences Between Participant Groups and Training Forms. Discussion Paper No. 03-57, Centre for European Economic Research (ZEW), Mannheim.

Loewenstein, M. A., and J. R. Spletzer (2000): General and Specific Training. Evidence and Implications. Journal of Human Ressources, 34(4), pp. 710-733.

Nagypál, É. (2004): Learning-by-Doing Versus Learning About Match Quality: Can We Tell Them Apart?. Unpublished Manuscript, Northwestern University, Evanston and Chicago.

Newey, W. K. (1987): Efficient Estimation of Limited Dependent Variable Models with Endogenous Explanatory Variables. Journal of Econometrics, 36, pp. 231-250.

Oi, W. (1962): Labor as a Quasi-Fixed Factor. Journal of Political Economy, 6, pp. $538-555$.

Owan, H. (2004): Promotion, Turnover, Earnings, and Firm-Sponsored Training. Journal of Labor Economics, 22(4), pp. 955-978.

Pannenberg, M. (1995): Weiterbildungsaktivitäten und Erwerbsbiographie. Frankfurt, New York: Campus.

Pfeiffer, F. (2001): Training and Individual Performance: Evidence from Microeconometric Studies. In: Training in Europe, Second Report on Vocational Training Research in Europe 2000: Background Report, CEDEFOP Reference Series Bd.3, pp. 7-41. Pascaline Descy und Manfred Tessaring, Luxemburg.

Pfeiffer, F., and F. Reize (2001): Formelle und Informelle Berufliche Weiterbildung und Verdienst bei Arbeitnehmern und Selbstständigen. In: Bildung und Beschäftigung, ed. by R. K. Weizsäcker, no. 284 in Schriften des Vereins für Socialpolitik, pp. 215274. Duncker und Humblot, Berlin.

Pischke, J.-S. (2001): Continuous Training in Germany. Journal of Population Economics, 14, pp. 523-548. 
Quercioli, E. (2005): Training, Turnover, and Search. International Economic Review, 46(1), pp. 133-143.

Spletzer, J., and M. Loewenstein (1998): Dividing the Costs and Returns to General Training. Journal of Labor Economics, 16(1), pp. 142-171.

Wasmer, E. (2003): Interpreting European and US Labour Market Differences: The Specificity of Human Capital Investments. Discussion Paper No. 3780, CEPR, London.

Weiß, R. (2003): Betriebliche Weiterbildung 2001. Ergebnisse einer IW-Erhebung. iwtrends $1 / 2003$.

Wolf, E., and T. Zwick (2002): Produktivitätswirkung von Mitarbeiterbeteiligung: Der Einfluss von unbeobachteter Heterogenität. Mitteilungen aus der Arbeitsmarkt- und Berufsforschung, 35, pp. 123-132.

Wooldridge, J. M. (2002): Econometric Analysis of Cross Section and Panel Data. Cambridge and London: MIT Press.

Zweimüller, J., and R. Winter-Ebmer (2003): On-the-Job Training, Job Search and Job Mobility. Swiss Journal of Eonomics and Statistics, 139(4), pp. 563-576. 


\section{A Appendix}

Table 6: List of variables used

\begin{tabular}{|c|c|c|}
\hline Variable & $\begin{array}{c}\text { Share/ } \\
\text { Average }\end{array}$ & Notes \\
\hline
\end{tabular}

School Attainment

Without School Leaving Certificate

Lower Secondary School

Intermediate Secondary School

Entrance to

University for Applied Sciences

High School Diploma

Vocational Training

Without Professional Degree

Full-Time Vocational School

Dual Apprenticeship

Master Craftsman

University for Applied Sciences

University

Training

Courses and Seminars

Courses and Seminars before 1997

\section{Professional Career}

Professional Experience

Company Tenure

Unemployment

\section{Professional Status \\ Unskilled Blue-Collar Worker \\ Skilled Blue-Collar Worker}

Assistant Foreman

Master/Foreman

Unskilled White-Collar Worker
$2.01 \%$

$36.45 \%$

$35.56 \%$ Reference category

$7.24 \%$

$18.73 \%$

$10.15 \%$

$2.22 \%$ Several years of professional training in school; reference category

$59.30 \%$ Several years of professional training in school and on-the-job

$10.46 \%$

$6.42 \%$

$10.66 \%$

43.86\% Participation in courses and seminars during the last 5 years

$16.77 \%$ Participation in courses and seminars

before 1997

21.02 years Years from first job until today

11.76 years Years from starting to work for a company until today

$30.37 \%$ Dummy $=1$ if a person was ever employed, otherwise 0

$11.90 \%$ Worker without professional degree

$18.53 \%$ Worker with degree from dual apprenticeship system or full-time vocational school; Reference category 
Table 6: List of variables used (continued)

\begin{tabular}{|c|c|c|}
\hline Variable & $\begin{array}{l}\text { Share/ } \\
\text { Average }\end{array}$ & Notes \\
\hline White Collar-Worker With & & \\
\hline Simple Tasks & $8.35 \%$ & \\
\hline White Collar-Worker With & & \\
\hline Difficult Tasks & $18.57 \%$ & \\
\hline High-Skilled White-Collar Worker & $19.50 \%$ & \\
\hline Executive White-Collar Worker & $5.53 \%$ & \\
\hline Job Change & $69.40 \%$ & \\
\hline Job Change after Training & $11.26 \%$ & $\begin{array}{l}\text { Dummy }=1 \text { if there is job change } \\
\text { after training, Dummy }=0 \text { if there } \\
\text { is training and no job change after }\end{array}$ \\
\hline Training1 & $23.54 \%$ & $\begin{array}{l}\text { Dummy }=1 \text { if training takes place } \\
\text { before possible job change, Dummy }=0 \\
\text { if there is no training }\end{array}$ \\
\hline Job Change (1984 - 1994) & $63.91 \%$ & Job Change between 1984 and 1994 \\
\hline Job Change after 1994 & $22.64 \%$ & \\
\hline Training before 1997 & $16.77 \%$ & \\
\hline Occupational Change & $32.90 \%$ & \\
\hline Occupational Change after Training & $5.80 \%$ & \\
\hline Task Change & $28.86 \%$ & \\
\hline Task Change after Training & $9.22 \%$ & \\
\hline Number of Employers & & 5 Categories: $1,2,3,4,5$ or more employers \\
\hline Task Change after Training & $9.22 \%$ & \\
\hline Occupational Change (Health) & $1.81 \%$ & Occupational Change for Health Reasons \\
\hline Occupational Change (Family) & $2.64 \%$ & Occupational Change for Family Reasons \\
\hline Firm Failure & $14.72 \%$ & \\
\hline \multicolumn{3}{|l|}{ Workplace Characteristics } \\
\hline Computer Work Station & $54.59 \%$ & $\begin{array}{l}\text { Work routine includes using } \\
\text { the computer }\end{array}$ \\
\hline Temporary Work & $7.77 \%$ & \\
\hline Overtime & $78.50 \%$ & $\begin{array}{l}\text { Dummy }=1 \text { if a person works } \\
\text { overtime, otherwise } 0\end{array}$ \\
\hline Profit-Sharing & $7.64 \%$ & \\
\hline Incentive Wage & $19.13 \%$ & \\
\hline Working Hours & 4.14 & \\
\hline Job Content & & $\begin{array}{l}13 \text { Categories: training, testing, } \\
\text { procurement, organisation, marketing, } \\
\text { developing, manufacturing, } \\
\text { negotiating, supervising, research, } \\
\text { repairing, counselling, monitoring }\end{array}$ \\
\hline
\end{tabular}

Individual Characteristics

Children

$45.39 \%$ Dummy $=1$ if a person has at 
Table 6: List of variables used (continued)

\begin{tabular}{|c|c|c|}
\hline Variable & $\begin{array}{c}\text { Share/ } \\
\text { Average }\end{array}$ & Notes \\
\hline & & least one child, otherwise 0 \\
\hline Child $<6$ y & $14.92 \%$ & $\begin{array}{l}\text { Dummy }=1 \text { if a person has at } \\
\text { least one child below } 6 \text { years, otherwise } 0\end{array}$ \\
\hline Child6to17y & $28.94 \%$ & $\begin{array}{l}\text { Dummy }=1 \text { if a person has at } \\
\text { least one child above } 6 \text { and } \\
\text { below } 17 \text { years, otherwise } 0\end{array}$ \\
\hline Child6to17y & $10.84 \%$ & $\begin{array}{l}\text { Dummy }=1 \text { if a person has at } \\
\text { least one child above } 18 \text { years, otherwise }\end{array}$ \\
\hline Foreigner & $5.43 \%$ & $\begin{array}{l}\text { Dummy }=1 \text { if a person does } \\
\text { not have a German Nationality, } \\
\text { otherwise } 0\end{array}$ \\
\hline Not Married & $8.42 \%$ & \\
\hline Female & $32.24 \%$ & \\
\hline Handicapped & $3.78 \%$ & \\
\hline Partner Employed & $38.51 \%$ & \\
\hline Size of Household & & 3 Categories: 2,3 or 4 household member \\
\hline Identifying Variables & & \\
\hline Technical Restructuring & $24.68 \%$ & \\
\hline Organisational Restructuring & $15.77 \%$ & \\
\hline Restructuring & 2.33 & Number of restructuring measures (1997/ \\
\hline Need for Training & 1.13 & $\begin{array}{l}\text { Number of areas with a subjective } \\
\text { need for training }\end{array}$ \\
\hline Instrument1 & 9.05 & $\begin{array}{l}\text { Share of firms, where training is part of } \\
\text { the collective agreement (industrial level) }\end{array}$ \\
\hline \multicolumn{3}{|l|}{ Employer Characteristics } \\
\hline Size of Firm & & $\begin{array}{l}7 \text { Categories: number of employees } \\
\text { is } 1-4,5-9,10-49 \text { (reference } \\
\text { category), 50-99, 100-499, 500-999, } \\
\text { and } 1000 \text { and more }\end{array}$ \\
\hline East Germany & $19.80 \%$ & \\
\hline Economic Sector & & 47 Categories \\
\hline Trade Sector & $12.30 \%$ & \\
\hline Industrial Sector & $25.80 \%$ & \\
\hline Private Household Sector & $0.36 \%$ & \\
\hline Public Service Sector & $26.95 \%$ & \\
\hline Handcraft Sector & $17.45 \%$ & \\
\hline Agricultural Sector & $1.34 \%$ & \\
\hline Good Economic Situation & $80.82 \%$ & $\begin{array}{l}\text { Dummy }=1 \text { if the company is in a good } \\
\text { economic situation, otherwise } 0\end{array}$ \\
\hline
\end{tabular}


Table 7: Translation of selected variables

\begin{tabular}{|c|c|}
\hline English & German \\
\hline \multicolumn{2}{|r|}{ Training } \\
\hline Quality Circle & Qualitätszirkel \\
\hline Trade Fair & Fachmesse \\
\hline Internship & Praktikum \\
\hline Lecture & Fachvortrag \\
\hline Specialist Literature & Fachliteratur \\
\hline \multicolumn{2}{|r|}{ School Attainment } \\
\hline Without School Leaving Certificate & Ohne Abschluss \\
\hline Lower Secondary School & Hauptschule \\
\hline Intermediate Secondary School & Realschule \\
\hline $\begin{array}{l}\text { Entrance to } \\
\text { University for Applied Sciences }\end{array}$ & Fachhochschulreife \\
\hline High School Diploma & Abitur \\
\hline \multicolumn{2}{|r|}{ Vocational Training } \\
\hline Without Professional Degree & Ohne Ausbildung \\
\hline Full-Time Vocational School & Berufsfachschule \\
\hline Apprenticeship & Lehre \\
\hline Master Craftsman & Meister \\
\hline University for Applied Sciences & Fachhochschule \\
\hline University & Universität \\
\hline \multicolumn{2}{|r|}{ Professional Status } \\
\hline Unskilled Blue-Collar Worker & Angelernter Arbeiter \\
\hline Skilled Blue-Collar Worker & Facharbeiter \\
\hline Assistant Foreman & Vorarbeiter \\
\hline Master/Foreman & Meister \\
\hline Unskilled White-Collar Worker & Ausführender Angestellter \\
\hline $\begin{array}{l}\text { White-Collar Worker with Simple } \\
\text { Tasks }\end{array}$ & Angestellter mit einfacher Tätigkeit \\
\hline $\begin{array}{l}\text { White-Collar Worker with Difficult } \\
\text { Tasks }\end{array}$ & $\begin{array}{l}\text { Angestellter, der schwierige Aufgaben nach allgemeiner } \\
\text { Anweisung selbständig erledigt }\end{array}$ \\
\hline High-Skilled White-Collar Worker & $\begin{array}{l}\text { Angestellter, der selbständige Leistungen in } \\
\text { verantwortungsvoller Tätigkeit erbringt oder begrenzte } \\
\text { Verantwortung für die Tätigkeit anderer trägt }\end{array}$ \\
\hline Executive White-Collar Worker & $\begin{array}{l}\text { Angestellter mit umfassenden Führungsaufgaben und } \\
\text { Entscheidungsbefugnissen }\end{array}$ \\
\hline Civil Servant in Clerical Grade & Beamter im einfachen oder mittleren Dienst \\
\hline Civil Servant in Higher Service & Beamter im gehobenen Dienst \\
\hline Civil Servant in Senior Service & Beamter im höheren Dienst \\
\hline
\end{tabular}


Table 8: First stage: Probit model for participation in training

\begin{tabular}{|c|c|c|}
\hline Variable & Coefficient & (Std. Err.) \\
\hline Training in 1991 & $0.416^{*}$ & $(0.176)$ \\
\hline \multicolumn{3}{|c|}{ Individual Characteristics } \\
\hline More than two Previous Employers & $0.108^{* *}$ & $(0.033)$ \\
\hline Professional Experience & $0.030^{* *}$ & $(0.006)$ \\
\hline Professional Experience Squared & $-0.001^{* *}$ & $(0.000)$ \\
\hline Unemployment & $0.099^{* *}$ & $(0.033)$ \\
\hline Age & 0.004 & $(0.005)$ \\
\hline Lower Secondary School & $-0.156^{* *}$ & $(0.038)$ \\
\hline Entrance to University for Applied Sciences - & -0.068 & $(0.067)$ \\
\hline High School Diploma & 0.007 & $(0.057)$ \\
\hline Without School Leaving Certificate & -0.097 & $(0.111)$ \\
\hline Without Professional Degree & $-0.220^{* *}$ & $(0.054)$ \\
\hline University for Applied Sciences & -0.037 & $(0.073)$ \\
\hline University & -0.066 & $(0.072)$ \\
\hline
\end{tabular}

\section{Other Controls}

Not Married, East Germany, Household Size (3), Sex, Children, FullTime Vocational School, Master Craftsman, Temporary Work, Computer Work Station, Size of Firm (6), White-Collar Worker, Economic Sectors (4), Overtime, Profit-Sharing, Incentive Wage, Working Hours, Partner Employed, Occupational Change (2), Restructuring, Need for Training

\begin{tabular}{lc}
\hline Intercept & $-2.588^{* *}$ \\
\hline $\mathrm{N}$ & $(0.180)$ \\
\hline Log-likelihood & 12578 \\
$\chi_{(41)}^{2}$ & -4981.645 \\
\hline
\end{tabular}

Significance levels : $\quad \dagger: 10 \% \quad *: 5 \% \quad * *: 1 \%$ 
Table 9: First stage: Probit model for employer change. Children between 6 and 17 and employed dummy for partner as instruments

\begin{tabular}{|c|c|c|}
\hline Variable & Coefficient & (Std. Err.) \\
\hline Partner Employed & $-0.225^{\dagger}$ & $(0.122)$ \\
\hline Child6to17y & 0.116 & $(0.086)$ \\
\hline \multicolumn{3}{|c|}{ Individual Characteristics } \\
\hline More than two Previous Employers & 0.144 & $(0.092)$ \\
\hline Professional Experience & -0.020 & $(0.018)$ \\
\hline Professional Experience Squared & 0.000 & $(0.000)$ \\
\hline Company Tenure & $-0.379^{* *}$ & $(0.081)$ \\
\hline Company Tenure Squared & $-0.032^{*}$ & $(0.013)$ \\
\hline Unemployment & $0.371^{* *}$ & $(0.076)$ \\
\hline Age & 0.008 & $(0.013)$ \\
\hline Lower Secondary School & 0.038 & $(0.104)$ \\
\hline Entrance to University for Applied Sciences & -0.182 & $(0.137)$ \\
\hline High School Diploma & 0.087 & $(0.120)$ \\
\hline Without School Leaving Certificate & -0.009 & $(0.252)$ \\
\hline Without Professional Degree & -0.078 & $(0.163)$ \\
\hline University for Applied Sciences & -0.069 & $(0.145)$ \\
\hline University & $-0.233^{\dagger}$ & $(0.140)$ \\
\hline
\end{tabular}

\section{Other Controls}

Not Married, Foreigner, Handicapped, East Germany, Household Size (3), Sex, Children, Full-Time Vocational School, Master Craftsman, Temporary Work, Computer Work Station, Size of Firm (6), WhiteCollar Worker, Economic Sectors (47), Overtime, Profit-Sharing, Incentive Wage, Working Hours, Partner Employed, Occupational Change (2), Firm Failure, Restructuring, Need for Training

\begin{tabular}{|c|c|}
\hline Intercept & $(0.628)$ \\
\hline $\mathrm{N}$ & 5026 \\
\hline Log-likelihood & -868.111 \\
\hline$\chi_{(87)}^{2}$ & 775.61 \\
\hline
\end{tabular}

Significance levels : $\quad \dagger: 10 \% \quad *: 5 \% \quad * *: 1 \%$ 
Table 10: Non-participants in training: Correlation between job change and wages

\begin{tabular}{lcc}
\hline \hline \multicolumn{1}{c}{ Variable } & Coefficient & (Std. Err.) \\
\hline \multicolumn{1}{c}{ Individual Characteristics } \\
\hline More than two Previous Employers & $0.042^{* *}$ & $(0.012)$ \\
Professional Experience & $0.006^{* *}$ & $(0.008)$ \\
Professional Experience Squared & $0.000^{* *}$ & $(0.002)$ \\
Company Tenure & $0.007^{* *}$ & $(0.002)$ \\
Company Tenure Squared & 0.000 & $(0.000)$ \\
Unemployment & $-0.053^{* *}$ & $(0.008)$ \\
Alter & $0.005^{* *}$ & $(0.001)$ \\
Lower Secondary School & $-0.026^{* *}$ & $(0.009)$ \\
Entrance to University for Applied Sciences & $0.081^{* *}$ & $(0.018)$ \\
High School Diploma & $0.060^{* *}$ & $(0.015)$ \\
Without School Leaving Certificate & 0.009 & $(0.023)$ \\
Without Professional Degree & $-0.086^{* *}$ & $(0.011)$ \\
University for Applied Sciences & $0.126^{* *}$ & $(0.023)$ \\
University & $0.241^{* *}$ & $(0.023)$ \\
\hline
\end{tabular}

\section{Other Controls}

Not Married, Foreigner, Handicapped, East Germany, Household Size (3), Sex, Children, Full-Time Vocational School, Master Craftsman, Temporary Work, Computer Work Station, Size of Firm (6), Professional Position (2), Economic Sectors (47), Overtime, Profit-Sharing, Incentive Wage, Working Hours, Occupational Change (2)

\begin{tabular}{|c|c|}
\hline Intercept & $7.541^{* *}$ \\
\hline$\overline{\mathrm{N}}$ & 9305 \\
\hline $\mathrm{R}^{2}$ & 0.422 \\
\hline $\mathrm{F}_{(86,9218)}$ & 69.367 \\
\hline
\end{tabular}


Table 11: First stage: Probit model for employer change. Children between 6 and 17 and employed dummy for partner as instruments

\begin{tabular}{lcc}
\hline \hline \multicolumn{1}{c}{ Variable } & Coefficient & (Std. Err.) \\
\hline \multicolumn{1}{c}{ Partner Employed } & $0.327^{* *}$ & $(0.112)$ \\
Child6to17y & $-0.449^{* *}$ & $(0.134)$ \\
\hline \multicolumn{3}{c}{ More than two Previous Employers } \\
Professional Experience & $1.091^{* *}$ & $(0.085)$ \\
Professional Experience Squared & $0.241^{* *}$ & $(0.017)$ \\
Company Tenure & $-0.005^{* *}$ & $(0.000)$ \\
Company Tenure Squared & $1.755^{* *}$ & $(0.111)$ \\
Unemployment & $-0.466^{* *}$ & $(0.021)$ \\
Age & $0.491^{* *}$ & $(0.076)$ \\
Lower Secondary School & $0.018^{\dagger}$ & $(0.010)$ \\
Entrance to University for Applied Sciences & 0.183 & $(0.091)$ \\
High School Diploma & -0.047 & $(0.161)$ \\
Without School Leaving Certificate & $-0.388^{\dagger}$ & $(0.125)$ \\
Without Professional Degree & $-0.305^{* *}$ & $(0.096)$ \\
University for Applied Sciences & -0.094 & $(0.193)$ \\
University & -0.016 & $(0.167)$ \\
\hline
\end{tabular}

\section{Other Controls}

Not Married, Foreigner, Handicapped, East Germany, Household Size (3), Sex, Children, Full-Time Vocational School, Master Craftsman, Temporary Work, Computer Work Station, Size of Firm (6), WhiteCollar Worker, Economic Sectors (47), Overtime, Profit-Sharing, Incentive Wage, Working Hours, Occupational Change (2)

\begin{tabular}{|c|c|}
\hline Intercept & -0.600 \\
\hline $\mathrm{N}$ & 10723 \\
\hline Log-likelihood & -904.771 \\
\hline$\chi_{(87)}^{2}$ & 893.680 \\
\hline
\end{tabular}


Table 12: Non-participants in training: IV estimates of the effect of job change on wages

\begin{tabular}{lcc}
\hline \hline \multicolumn{1}{c}{ Variable } & Coefficient & (Std. Err.) \\
\hline \multicolumn{2}{c}{ Individual Characteristics } \\
\hline More than two Previous Employers & 0.013 & $(0.014)$ \\
Professional Experience & $0.006^{* *}$ & $(0.008)$ \\
Professional Experience Squared & $0.000^{* *}$ & $(0.002)$ \\
Company Tenure & $0.006^{* *}$ & $(0.000)$ \\
Company Tenure Squared & 0.000 & $(0.000)$ \\
Unemployment & $-0.053^{* *}$ & $(0.008)$ \\
Age & $0.005^{* *}$ & $(0.001)$ \\
Lower Secondary School & $-0.026^{* *}$ & $(0.009)$ \\
Entrance to University for Applied Sciences & $0.081^{* *}$ & $(0.018)$ \\
High School Diploma & $0.060^{* *}$ & $(0.015)$ \\
Without School Leaving Certificate & 0.008 & $(0.023)$ \\
Without Professional Degree & $-0.087^{* *}$ & $(0.011)$ \\
University for Applied Sciences & $0.126^{* *}$ & $(0.023)$ \\
University & $0.242^{* *}$ & $(0.023)$ \\
\hline
\end{tabular}

Other Controls

Not Married, Foreigner, Handicapped, East Germany, Household Size (3), Sex, Children, Full-Time Vocational School, Master Craftsman, Temporary Work, Computer Work Station, Size of Firm (6), Professional Position (2), Economic Sectors (47), Overtime, Profit-Sharing, Incentive Wage, Working Hours, Occupational Change (2)

\begin{tabular}{lcc}
\hline Intercept & $7.545^{* *}$ & $(0.081)$ \\
\hline & & \\
\hline $\mathrm{N}$ & & 9305 \\
$\mathrm{R}^{2}$ & 0.422 \\
$\mathrm{~F}$ (86,9218) & 69.381 \\
\hline Significance levels : $\dagger: 10 \% \quad *: 5 \% \quad * *: 1 \%$ &
\end{tabular}

